\title{
Performance Improvement In Order To Improve Competitiveness Analysis On Supply Chain Management Integration Strategy Leather Industry In Tanggulangin
}

\author{
Dr. Rupiarsieh, M.Si \\ Social and Politic Faculty, Bojonegoro University, East Java, Indonesia \\ Ir. Sutoro Haryo Santosa, SE, MM \\ STIE IEU SURABAYA, East Java, Indonesia
}

\begin{abstract}
Supply Chain Management (SCM) is the over sight of material, information and finances as they move in a process from supplier to manufactures to consumer. Supply Chain Management involves coordinating and integrating these flows and base on Frohlich and Roy Westbrook (2001) there are 5 (five) types of integration: Inward-facing, periphery-facing, supplier-facing, customer-facing and out word facing. The variable of the type of integration are: access to planning systems, sharing production plans, join EDI access / networks, knowledge of inventory mix / levels, packaging customidation, delivery frequencies, common use of third - party logistics, with performance variables: financial perspective, customer perspective serta interval business process perspective. This research was investigated the correlation between the type of integration with the corporate performance in Financial Perspective, Customer Perspective and Internal Business Process Perspective. The data was get from the leather industry on Cluster Tanggulangin Sidoarjo. The result of the research as: There strong correlation between the type of integration quality of integration and industry performance. The benefit of the research is: there is possible to create the model of the correlation between the type of integration, quality of integration and the corporate performance that be able to choose the strategy of Supply Chain Management, to be used as inputs for policy makers to provide coaching and development of the leather industry in Sidoarjo Regency or another places with the same typology.
\end{abstract}

Key word: Supply Chain Management, type of integration, industrial performance

\section{PREFACE}

Rapid technological developments in all areas affecting the availability of goods produced and its selling in the market. Improvement and product innovation is always going to make the goods become obsolete and unmarketable. The emergence of an industry that has rehabilitated could lead to products from these industries are flooding the market both in number and kind of a more diverse and more competitive. Companies competition increase sharply, and more competitive to attract consumers in an effort to maintain its existence in order to stay alive from the buyer's decision, therefore, companies need to change their old paradigm to the new paradigm.

The new paradigm of engaging consumers in their production process, with the intention to grow the organization who are able to establish an ongoing relationship between consumers and industry.

More than a decade ago there was an increase consensus related to the importance of the integration of suppliers, manufacturers and customers. As stated by Carothers and Adam 
(1991), Langley and Holcomb (1992), and Shapiro et al (1993) revealed one subject logistics has become a comprehensive topic that is currently spread throughout the values system of the supplier to the customer. Ragatz et al (1997) noted that effective integration of suppliers into the supply chain, the value of the product will be a key factor for some manufacturers to meet the increasing need to maintain its competitiveness. Many theoretical arguments for the integration of operations, closely between the manufacturer with suppliers and customers are from the literature reengineer process. The goal is to create and coordinate the processing without limit throughout the supply chain where the competitors can not fill up easily (Anderson and Katz 1998; Lumus et al 1998 ) ..

Saunders (1997), Trent and Monezka (1998), shows that there are two forms of relationships that were developed enterprise integration. The first type of integration is the integration and coordination of the future (forward) of the physical delivery flow or suppliers, manufacturers and customers. The second types of integration is coordination of information technology backward and the flow of data from the customer to the supplier (Martin 1992; Trent and Monezka 1998) . Various empirical evidence shows that the higher level of integration with suppliers and customers in the supply chain will be even greater potential returns (Stevens 1989; Lee et al, 1997; Narasimhan and Jayaram, 1998; Lummus et al, 1998; Anderson and Katz, 1998; Hines et al, 1998; Johnson, 1999).

Handfield and Nichols (1999) argues that at this time the manufacturer or the company should not only manage their own organization, but also engage in its management of upstream and downstream enterprises networking. Hake (1999) shows that companies that have traditionally been structured as independent businesses will increase operating configuration in a basic division. Furthermore, the manufacturer or the company with a bow most comprehensive supply chain integration should have improved the highest level of performance.

The leather industry in Tanggulangin - Sidoarjo, is the center of the leather industry with incidentaly supply chain; it means that the relationship between the supplier and the industry has not been built in the form of a permanent chain. The leather industry in Tanggulangin Sidoarjo is owned by Local Government, that must be maintained in their existence, because it has a strategic function, which is a source of income for the people and the sources of local governments income. Base on the description above, this study focuses on how to design a research strategy of supply chain management (SCM) in coordination with suppliers and the customers with their effect on the performance of the company's leather industry in Tanggulangin - Sidoarjo. The aim of this study is to provide input to policy makers in order to provide guidance and development of leather industry in Sidoarjo.

\section{THE METHOD OF RESEARCH}

The operational concept of this research design by using the Arc of Integration Method) through the cooperation of upstream and downstream SCM. Then, will be known the typology of integration position and level of the company.

To know that, the nextsteps that must be taken is preceded by the stage of data collection through questionnaire about SCM using 8 (eight) integrative activity both from the supplier and from customers. The next step is to analyze the data by using factor analysis. From the analysis of these factors will be obtained factor score (FS) both from the supplier and from the customers. Based on this FS distribution, the integration degree of the companies can be determined. 
The company performance the company will be able to be measured by using the balance score card (BSC) with using three (3) perspectives: financial perspective, customer perspective and internal business process perspective.

To find out dependencies or to determine whether there is a difference between the influence of typology SCM integration with company performance and the steps is taken to conduct a test dependencies using Analysis of Variance (ANOVA). The result of Anova will be obtained if there are differences in the company's performance, in terms of perceptions of BSC in the various typologies of integration that has been formed and at the same time it will be able to test the hypothesis.

The Design of this research can be decribed as follows:

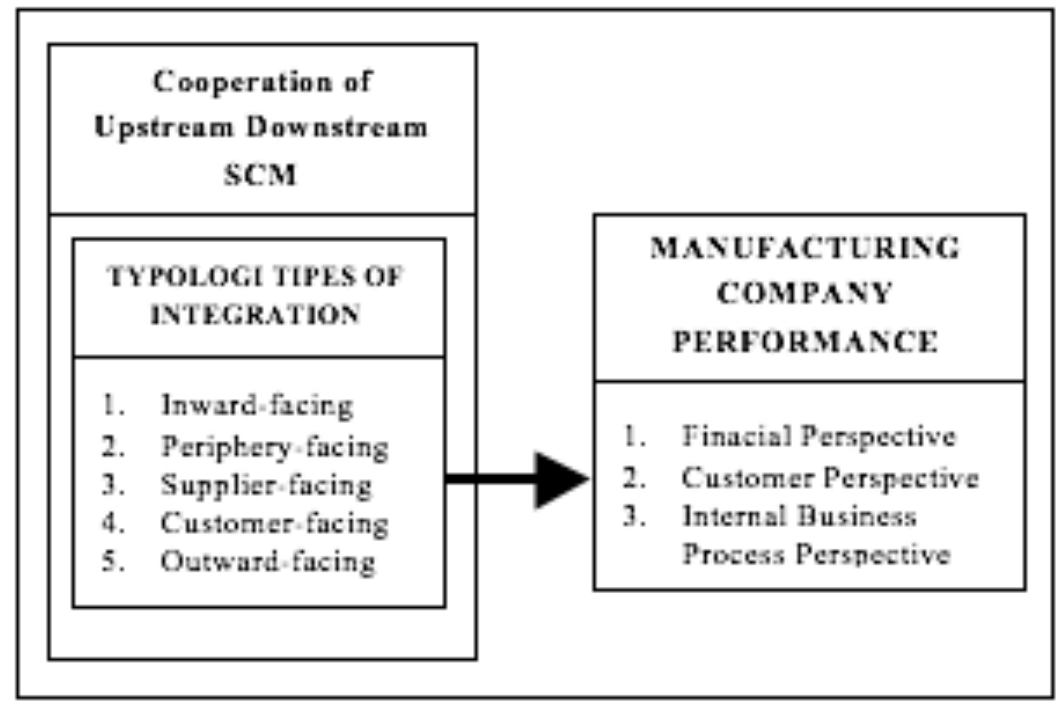

Figure 1. The Framework of Research Design

\section{RESULTS \\ LEATHER INDUSTRY TANGGULANGIN}

There are 264 leather industries in this studies, and devided in three category: Large, Medium and Small. There are 75 members of small industries, 138 members of midlle industries ang 51 members of large industries. Industrial categorization based on the evaluation of the researcher. Small industries put their product in one showroom, midlle industries put the product in many showroom and the large industries make the product in large scale and have their own showroom and also send the product to another many showroom

\section{Identification of Integration Typology}

There ara five (5) integration typology: Inward Facing, Periphery Facing, Supplier Facing, Costumer Facing, Outward Facing. The data obtained show that there is a typology groupings as follows:

1. Inward Facing, in large industry that agree is only $20 \%$, the medium industry is $0 \%$, and $32 \%$ of small industries.

1. Periphery Facing, in large industry that agree is only $25 \%$, the medium industry $15 \%$, and small industry $32 \%$.

2. Supplier Facing, in large industry that agree is only $6 \%$, medium industry $0 \%$, and small industry $28 \%$.

3. Costumer Facing, in large industry that agree is only $10 \%$, medium industry $2 \%$, and small industry $28 \%$.

4. Outward Facing. In large industry taht agree is only $95 \%$, medium industry $96 \%$, and small industry $92 \%$. 
The typology of the integration of the leather industry in Tanggulangin is outward facing, with a very large dependence on suppliers and customers who have been visiting / shopping in these places (shopping)

\section{Effect of Typology Against Corporate Performance.}

From the data above, the only typology outward facing (>90\%) of cultivable performance becouse the other typologies are too small influence

\section{Corporate Performance Measurement.}

In accordance with the study design, from four perspectives of the Balanced Scorecard (BSC) taken three perspectives: (1) finacial perspective, (2) customer perspective, (3) internal business perspective; show that there are the difference between large industry, medium, and small.

\section{Financial Perspective:}

The return of capital, only large industry that according to the plan (80\%), while the medium industry is $15 \%$, and $32 \%$ of small industries . There is also on profit and profit increased, and in large industry (85\%) but not for the other industries. For medium and small industries need to be arranged the return capital strategy according to plan and profit improvement strategy. The easiest way to imitate on a particularly large industrial capital return strategy and strategy of the company's profit

\section{Customer Perspective:}

Especially for the customer perspective, the result is shown in Appendix D. There is the difference between large, medium, and small industry.

1. The big industry dominate the market share is $90 \%$, the level of customer trust is $75 \%$, speed and time of order completion is $100 \%$ ) and the good image of customers is $85 \%$

2. In medium industry is superior in quality of service (81\%). The level of customer satisfaction on service quality is $80 \%$.

3. Small industry is superior in the quality of product (80\%).

Thus, the performance improvement can be started with a strategy of openness that allow other companies to imitate the success that has been achieved.

\section{Internal Business Perspective:}

According to Kaplan and Norton (1996), this process consists of three stages, namely the Innovation Process, Operation Process, and After Sales Service. The data show that almost all of the industry is weak in the area of internal processes mainly innovation process / product development.

\section{ANALYSIS OF SUPPLY CHAIN PERFORMANCE FACTOR}

To improve the performance of supply chain management among suppliers, manufacturing, and customer needs Upstream Supply Chain Management to integrate supplier with manufacturing and downstream Supply Chain Management to integrate the customer with manufactur. Continuous control of eight main activities, namely:

Access to planning system

Sharing production plans

Joint EDI access/ networks

Knowledge of inventory mix/ level

Packaging customization

Delivery frequencies 
Comission logistical equipment / containers

Common use of third party logistic

As shown in appendix B, the analysis of large industries, medium, and small, showed different results. Therefore, performance improvement strategy is also different and reserved only for the performance has not been satisfactory, are as follows:

1. Strategi to increase performance by upgrading the systems of industrial planning for small and medium industry

2. Strategies to improve performance by increasing production planning capabilities in the industry especially for medium-sized industry

3. Strategies to improve performance in the form of inventory levels calculation training especially for small industry

4. Strategies in packaging aimed at small industries in order to improve performance

5. Strategies to improve the performance by increasing the frequency of handover is greatly affect the desire of consumers

6. Strategies to improve the performance is mainly aimed at small industries regarding to the importance of logistic supplies

7. The role of third parties in the area of procurement is not important, it is necessary to look for the procurement strategy to improve the performance.

\section{DISCUSSION}

\section{The Central of Leather Industries in Tanggulangin Sidoarjo}

1. From an analysis of the typology of the integration of the activities of the SCM among Supplier - Customer - Industrial companies in the centre of leather industry at Tanggulangin, Sidoarjo indicated that over $90 \%$ agree that Outward Facing Typology characterized by a very strong integration among suppliers, the leather industry, and customers. Supplier open a grocery store a hardware store, making it easier for industry to buy them. In normal conditions, consumers buy directly in Tanggulangin (shopping)

2. The Analysis of the influence of Integration typology on corporate, is limited to outward facing, since almost no other typology integration of the leather industry in Tanggulangin Sidoarjo

3. Performance improvement is possible, by the supply chain (a-h) and by the three BSC perspective (Financial, Customer, Internal Process)

4. Using the data, it can be arranged SWOT analysis as follows: 
Rupiarsieh., \& Santosa, S. H. (2019). Performance Improvement In Order To Improve Competitiveness Analysis On Supply Chain Management Integration Strategy Leather Industry In Tanggulangin. Advances in Social Sciences Research Journal, 6(2) 1-17.

\section{Leather Industry at Tanggulangin Sidoarjo is included in large categories:}

\begin{tabular}{|c|c|c|c|c|c|}
\hline Description & Factor & Score & Description & Factor & Score \\
\hline $\begin{array}{l}\text { Strength } \\
\end{array}$ & & & Opportunity & & \\
\hline $\begin{array}{l}\text { 1. Have access to the } \\
\text { planning system }\end{array}$ & +++ & 2 & $\begin{array}{l}\text { 2.Production planning } \\
\text { designed together }\end{array}$ & ++ & 2 \\
\hline \multirow[t]{2}{*}{$\begin{array}{l}\text { 3. control of inventory } \\
\text { levels }\end{array}$} & + & 2 & $\begin{array}{l}\text { 4. Integrated data } \\
\text { network }\end{array}$ & +++ & 2 \\
\hline & & & 5.Market Control & ++++ & 3 \\
\hline \multirow[t]{2}{*}{$\begin{array}{l}\text { 6. Frequency of delivery to } \\
\text { customers }\end{array}$} & +++ & 3 & $\begin{array}{l}\text { 7. Customers' } \\
\text { confidence to product }\end{array}$ & ++ & 3 \\
\hline & & & $\begin{array}{l}\text { 8. The influence of } \\
\text { packaging }\end{array}$ & +++ & 2 \\
\hline 9. Logistic supplies & +++ & 2 & $\begin{array}{l}10 . \\
\text { capital retun is } \\
\text { planned }\end{array}$ & ++ & 2 \\
\hline $\begin{array}{l}\text { 11. Big profit and } \\
\text { Acquiincreased }\end{array}$ & +++ & 2 & $\begin{array}{l}12 . \\
\text { customers' The } \\
\text { satisfaction in quality } \\
\text { of services }\end{array}$ & + & 3 \\
\hline $\begin{array}{l}\text { 13. The new product is } \\
\text { advantageous }\end{array}$ & ++ & 2 & $\begin{array}{l}14 . \\
\text { mers buy the product } \\
\text { in good quality }\end{array}$ & + & 3 \\
\hline $\begin{array}{l}\text { 15. Low level in failure } \\
\text { product }\end{array}$ & ++ & 3 & $\begin{array}{l}16 . \\
\text { customer's The } \\
\text { satisfaction in short } \\
\text { time of delivery }\end{array}$ & +++ & 3 \\
\hline $\begin{array}{l}\text { 17. The wasted of raw } \\
\text { matrial is low }\end{array}$ & + & 2 & $\begin{array}{ll}\begin{array}{c}18 . \\
\text { any image }\end{array} & \text { Comp } \\
\end{array}$ & +++ & 3 \\
\hline \multirow[t]{5}{*}{$\begin{array}{l}\text { 19. Production cost within } \\
\text { budget }\end{array}$} & +++ & 2 & $\begin{array}{l}20 . \\
\text { mer demand is } \\
\text { always fullfilled }\end{array}$ & +++ & 3 \\
\hline & & & $\begin{array}{l}21 . \\
\text { the product get } \\
\text { warranty }\end{array}$ & +++ & 3 \\
\hline & & & $\begin{array}{l}22 . \\
\text { repair and The } \\
\text { replacement of spare } \\
\text { parts in short time }\end{array}$ & + & 3 \\
\hline & & & $\begin{array}{l}23 . \\
\text { onsive to the } \\
\text { customers' need }\end{array}$ & ++ & 2 \\
\hline & & & $\begin{array}{l}24 . \\
\text { wasted matrial } \\
\text { polutted the } \\
\text { environment }\end{array}$ & + & 3 \\
\hline Weakness & & & Threats & & \\
\hline $\begin{array}{l}25 . \text { The dependency to } \\
\text { supplier is very high }\end{array}$ & --- & 2 & $\begin{array}{l}26 . \\
\mathrm{y} \text { from thir parties }\end{array}$ & - & 1 \\
\hline $\begin{array}{l}\text { 1. The dependency to the } \\
\text { customer is very high }\end{array}$ & --- & 3 & $\begin{array}{l}\text { 2. The dissatisfaction of } \\
\text { customer }\end{array}$ & - & 3 \\
\hline $\begin{array}{l}\text { 3. Less inovation in } \\
\text { creating products }\end{array}$ & - & 2 & $\begin{array}{l}\text { 1.Acquisition credits } \\
\text { payments not on time }\end{array}$ & -- & 2 \\
\hline $\begin{array}{l}\text { 2. High cost in creating } \\
\text { new products }\end{array}$ & -- & 2 & & & \\
\hline $\begin{array}{l}\text { 3. Creating new product } \\
\text { takes a long time }\end{array}$ & - - & 2 & & & \\
\hline $\begin{array}{l}\text { 4. Too many reworking } \\
\text { (because there are high } \\
\text { number of faliure } \\
\text { production) }\end{array}$ & & & & & \\
\hline
\end{tabular}


Leather Industry at Tanggulangin Sidoarjo is included in medium categories:

\begin{tabular}{|c|c|c|c|c|c|c|}
\hline Deskripsi & Faktor & Bobot & & Deskripsi & Faktor & Bobot \\
\hline $\begin{array}{r}\text { Kekuatan } \\
\text { (Strength): }\end{array}$ & & & & $\begin{array}{c}\text { Peluang } \\
\text { (Opportunity): }\end{array}$ & & \\
\hline $\begin{array}{l}\text { 1. Menguasai } \\
\text { perhitungan } \\
\text { tingkat persediaan }\end{array}$ & + & 2 & & $\begin{array}{l}\text { Perencanaan } \\
\text { produksi } \\
\text { dirancang } \\
\text { bersama-sama }\end{array}$ & +t & 2 \\
\hline $\begin{array}{l}\text { 3. Frekwensi } \\
\text { penyerahan ke } \\
\text { konsumen }\end{array}$ & + & 3 & 4. & $\begin{array}{l}\text { Jaringan data } \\
\text { yang } \\
\text { terintegrasi } \\
\end{array}$ & +++ & 2 \\
\hline $\begin{array}{l}\text { 5. Perlengkapan } \\
\text { logistic }\end{array}$ & +++ & 2 & & $\begin{array}{l}\text { Kemasan } \\
\text { sangat } \\
\text { mempengaruhi } \\
\text { konsumen } \\
\end{array}$ & ++ & 2 \\
\hline $\begin{array}{l}\text { 7. Produk baru } \\
\text { selalu } \\
\text { menguntungkan }\end{array}$ & +++ & 2 & & $\begin{array}{l}\text { Kepercayaan } \\
\text { pelanggan } \\
\text { terhadap } \\
\text { produk }\end{array}$ & ++ & 3 \\
\hline $\begin{array}{l}\text { 9. Tingkat kerusakan } \\
\text { produksi rendah } \\
\text { 38. }\end{array}$ & ++ & 3 & 10 & $\begin{array}{l}\text { Kepuasan } \\
\text { pelanggan } \\
\text { terhadap mutu } \\
\text { pelayanan }\end{array}$ & +++ & 3 \\
\hline $\begin{array}{l}\text { 11. Bahan baku } \\
\text { terbuang (waste) } \\
\text { rendah }\end{array}$ & + & 2 & & $\begin{array}{l}\text { Kepuasan } \\
\text { pelanggan } \\
\text { terhadap } \\
\text { produk }\end{array}$ & ++ & 3 \\
\hline $\begin{array}{l}\text { 13. Biaya produksi } \\
\text { sesuai anggaran }\end{array}$ & +++ & 2 & & $\begin{array}{l}\text { 4. Kepuasan } \\
\text { pelanggan } \\
\text { terhadap } \\
\text { kecepatan dan } \\
\text { waktu } \\
\text { penyerahan }\end{array}$ & +++ & 3 \\
\hline \multirow{6}{*}{54.} & & & & $\begin{array}{l}\text { Permintaan } \\
\text { pelanggan } \\
\text { selalu terpenui }\end{array}$ & ++ & 2 \\
\hline & & & & $\begin{array}{l}\text { Setiap produk } \\
\text { diberi garansi } \\
\text { kerusakan }\end{array}$ & n++ & 3 \\
\hline & & & & $\begin{array}{l}\text { Perbaikan } \\
\text { kerusakan dan } \\
\text { penggantian } \\
\text { suku cadang } \\
\text { cepat }\end{array}$ & +++ & 3 \\
\hline & & & & $\begin{array}{l}\text { Perolehan } \\
\text { tagihan cicilan } \\
\text { lancar }\end{array}$ & + & 3 \\
\hline & & & & $\begin{array}{l}\text { Kecepatan } \\
\text { menanggapi } \\
\text { keluhan } \\
\text { pelanggan } \\
\text { memuaskan }\end{array}$ & +++ & 3 \\
\hline & & & & $\begin{array}{l}\text { Tidak ada } \\
\text { limbah berbau }\end{array}$ & t++ & 3 \\
\hline $\begin{array}{c}\text { Kelemahan } \\
\text { (Weakness) : }\end{array}$ & & & & $\begin{array}{l}\text { 73. Ancaman } \\
\text { 74. (Threats) }\end{array}$ & & \\
\hline $\begin{array}{l}\text { 1. Ketergantungan } \\
\text { terhadap supplier } \\
\text { sangat besar }\end{array}$ & 77. & 2 & & $\begin{array}{l}\text { Supply dari } \\
\text { pihak ketiga }\end{array}$ & -- & 2 \\
\hline $\begin{array}{l}\text { 2. Ketergantungan } \\
\text { terhadap customer } \\
\text { sangat besar }\end{array}$ & -- & 3 & 3. & $\begin{array}{l}\text { Tidak } \\
\text { menguasai } \\
\text { pangsa pasar } \\
\end{array}$ & -- & 3 \\
\hline 86. & & & & $\begin{array}{l}\text { Pengembalian } \\
\text { modal tidak } \\
\text { sesuai rencana }\end{array}$ & --- & 2 \\
\hline $\begin{array}{l}\text { 5. Akses terhadap } \\
\text { sistem } \\
\text { perencanaan }\end{array}$ & -- & 2 & 6. & $\begin{array}{l}\text { Pengembalian } \\
\text { modal tidak } \\
\text { sesuai rencana }\end{array}$ & -- & 2 \\
\hline $\begin{array}{l}\text { 7. Besaran laba dan } \\
\text { tingkat } \\
\text { pertambahannya }\end{array}$ & -- & 2 & 8. & $\begin{array}{l}\text { Pelanggan } \\
\text { membeli } \\
\text { produk bukan } \\
\text { karena harga }\end{array}$ & - & 3 \\
\hline $\begin{array}{l}\text { 9. Kurang inovasi } \\
\text { produk baru }\end{array}$ & -- & 3 & 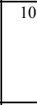 & $\begin{array}{l}\text { Pelanggan } \\
\text { membeli } \\
\text { produk bukan } \\
\text { karena } \\
\text { kualitas }\end{array}$ & 1. & 2 \\
\hline $\begin{array}{l}\text { 11. Biaya penciptaan } \\
\text { produk baru } \\
\text { tinggi }\end{array}$ & -- & 2 & 12 & $\begin{array}{l}\text { Citra } \\
\text { perusahaan } \\
\text { kurang baik } \\
\text { dimata } \\
\text { pelanggan }\end{array}$ & s. & 3 \\
\hline $\begin{array}{l}\text { 13. Penciptaan } \\
\text { produk baru perlu } \\
\text { waktu lama }\end{array}$ & -- & 2 & 09. & & 0. & 1. \\
\hline
\end{tabular}




\section{Leather Industry at Tanggulangin Sidoarjo is included in small categories:}

\begin{tabular}{|c|c|c|c|c|c|}
\hline Description & Factor & Score & Description & Factor & Score \\
\hline Strength & & & Opportunity & & \\
\hline $\begin{array}{l}\text { 1. Aaccess to the planning } \\
\text { system }\end{array}$ & + & 2 & $\begin{array}{l}\text { 2. Production planning } \\
\text { designed together }\end{array}$ & + & 2 \\
\hline $\begin{array}{l}\text { 3. The amount of profit and } \\
\text { increased }\end{array}$ & + & 2 & $\begin{array}{l}\text { 4. Integrated data } \\
\text { network }\end{array}$ & + & 2 \\
\hline 5. Market share & + & 2 & $\begin{array}{l}\text { 6. The customers' } \\
\text { satisfaction in quality } \\
\text { of services }\end{array}$ & + & 3 \\
\hline \multirow[t]{2}{*}{$\begin{array}{l}\text { 7. Production cost within } \\
\text { budget }\end{array}$} & ++ & 2 & $\begin{array}{l}\text { 8. Customers' } \\
\text { satisfaction to } \\
\text { product }\end{array}$ & + & 3 \\
\hline & & & $\begin{array}{l}\text { 9. Custumers buy the } \\
\text { product in good } \\
\text { quality }\end{array}$ & +++ & 3 \\
\hline & & & $\begin{array}{l}10 . \\
\text { customer's The } \\
\text { satisfaction in short } \\
\text { time of delivery }\end{array}$ & +++ & 3 \\
\hline . & & & $\begin{array}{l}11 . \\
\text { any image in midle } \\
\text { level }\end{array}$ & + & 3 \\
\hline t. & & & $\begin{array}{l}12 . \\
\text { mers demand always } \\
\text { fulfilled }\end{array}$ & ++ & 3 \\
\hline 5 & & & $\begin{array}{l}\text { 13. All } \\
\text { the product get } \\
\text { warranty }\end{array}$ & +++ & 2 \\
\hline 5. & & & $\begin{array}{l}14 . \\
\text { onsive to the } \\
\text { customers' need }\end{array}$ & + & 3 \\
\hline & & & $\begin{array}{l}15 . \\
\text { wasted matrial } \\
\text { polutted the } \\
\text { environment }\end{array}$ & ++ & 3 \\
\hline Weakness & & & Threats & & \\
\hline $\begin{array}{l}\text { 16. The dependency to the } \\
\text { supplier }\end{array}$ & -- & 2 & $\begin{array}{l}\text { suppl } \\
\text { y from thir parties }\end{array}$ & - & 2 \\
\hline $\begin{array}{l}\text { 1. The dependency to the } \\
\text { customer }\end{array}$ & -- & 3 & $\begin{array}{l}\text { 2. The custumers } \\
\text { distrust to the product }\end{array}$ & & 1 \\
\hline $\begin{array}{l}\text { 3. Can't predict the level of } \\
\text { matrial stock }\end{array}$ & & 1 & $\begin{array}{l}\text { 1. Acquisition credits } \\
\text { payments not on time }\end{array}$ & - & 2 \\
\hline 2. Packaging & & 1 & $\begin{array}{l}\text { 3. Customer buy } \\
\text { product not depend } \\
\text { on the price }\end{array}$ & & 1 \\
\hline $\begin{array}{l}\text { 4. Frequency of customers' } \\
\text { delivery }\end{array}$ & & 1 & $\begin{array}{l}\text { 5. The repair and } \\
\text { replacement of spare } \\
\text { parts in short time }\end{array}$ & & 3 \\
\hline 6. Logistic supply & - & 2 & $\begin{array}{l}\text { 7. Acquisition of the } \\
\text { payments is too slow }\end{array}$ & - & 3 \\
\hline $\begin{array}{l}\text { 8. Less inovation in } \\
\text { creating products }\end{array}$ & - & 2 & & & \\
\hline $\begin{array}{l}\text { 9. New Product not } \\
\text { profitable }\end{array}$ & & 1 & & & \\
\hline $\begin{array}{l}\text { 10. High cost in creating } \\
\text { new products }\end{array}$ & - & 2 & & & \\
\hline $\begin{array}{l}\text { 11. Branding image of new } \\
\text { product takes long time }\end{array}$ & - & 2 & & & \\
\hline $\begin{array}{l}\text { 12. The failure of product is } \\
\text { high }\end{array}$ & & 1 & & & \\
\hline $\begin{array}{l}\text { 13. Row Matrial is wasted in } \\
\text { high quantity }\end{array}$ & - & 2 & & & \\
\hline $\begin{array}{l}\text { 14. Reworking (because } \\
\text { there are high number of } \\
\text { faliure production) }\end{array}$ & - & 2 & & & \\
\hline
\end{tabular}

\section{Notes:}

\section{Factors :}

$+=\mathrm{S}-\mathrm{O}$

$-=\mathrm{W}-\mathrm{T}$

$50-60 \%=+\quad=$ less important

$61-80 \%=++\quad=$ important

$81-100 \%=++\quad=$ very important

\section{Weighing:}

1 = profitable only for unilateral

$2=$ profitable for bilateral

$3=$ profitable for multilateral or to customer.

The proposed strategy to improve the performance are:

1. The creation of a new product strategy for all industries, especially medium and small industries.

2. The product development strategy that produces maturity, especially in medium and small industries.

3. The product development strategy that resulted in lower costs for all industries. 
4. The product development strategy which resulted in the acceleration of the creation process of new products for all industries.

5. The strategy to overcome the failure of production mainly in small industrial.

6. The suppress stratety for wasted materials, especially in small industries.

7. The strategies to reduce rework, especially for large and small industries.

8. The strategies to provide a warranty for product damage, especially to the small industry.

\section{The Model of Relationship of the company's performance and the typology of supply chain integration management:}

Dalam bentuk tatanan hipotesis ditentukan persamaan yang menghubungkan

In the form of hypothesis is prescribed linking equation:

$\mathrm{Y}=$ company performance variable with variable of supply chain integration management typology.

$\mathrm{X} 1=$ inward - facing arc of integration

$\mathrm{X} 2=$ periphery - facing arc of integration

$\mathrm{X} 3=$ suppliers - facing arc of integration

$\mathrm{X} 4=$ customer - facing arc of integration

$\mathrm{X} 5=$ outward - facing arc of integration

$\mathrm{a}=$ slope of the line $\mathrm{Y}=\mathrm{a}+\mathrm{bx}$

$\mathrm{b}=$ The differentiate of the estimate change value $\mathrm{Y}$ over the estimate chage value $\mathrm{X}$

The linear equation connecting the company performance with integration typology

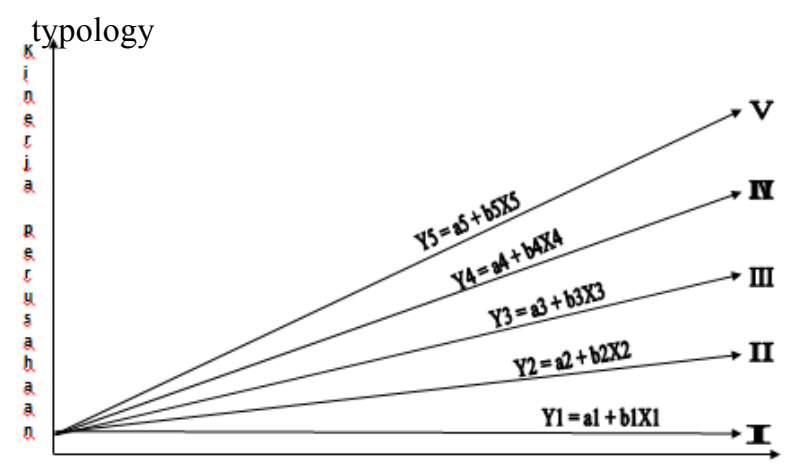

I. The company's performance is in the lowest position because the cooperation between customer and supplier is very low. In this research is found that consumers do not want to come to Tanggul-angin Leather Industry because they fear of Lapindo mud disaster. Although the relationship agreement among the customer, manufacture, and supplier are very high (outward facing arc of integration), but there is the cooperation obstacle makes the the changes of typology that impact on the company's performance. Thus, the equation $\mathrm{Y} 5=\mathrm{a}+\mathrm{b} 5 \mathrm{X} 5$ is changed to be $\mathrm{Y} 1=\mathrm{a} 1+\mathrm{b} 1 \mathrm{X} 1$, because there is the change of $\mathrm{X} 5$ to be $\mathrm{X} 1$ and the equation changed to be inward-facing arc of integration (I) Typology.

II. The company's performance is higher than the condition one (I) but remains low, because of the cooperation among the customer, manufacturing and suppliers are still many obstacles that can not be optimally took away the company's performance. In this research is found that there is an effort to market the leather products out of Tanggulangin. The most buyers comes from tourism. It makes the lower volume in selling. Then, changing market process in unsatisfacton. The suppliers are also very careful in cooperation with the manufactur.

Then, the equation $\mathrm{Y}=\mathrm{a}+\mathrm{b} 1 \mathrm{X} 1$ want to be changed but the performace is still in the equation $\mathrm{Y}=\mathrm{a}+\mathrm{b} 2 \mathrm{X} 2$. $\mathrm{X} 2$ is pherypery-facing arc of integration (II) Typology. 
III. The company's performance is higher than the second performance (II) because the supplier want to raise the performance of that business manufactur. In other hand, the business of the suppliers also increased, because the market is increased too. The equation $\mathrm{Y} 2=\mathrm{a} 2+\mathrm{b} 2 \mathrm{X} 2$ is wanted to be $\mathrm{Y} 3=\mathrm{a} 3+\mathrm{b} 3 \mathrm{X} 3$. It is Supplier Typology Facing Arc of Integration (III).

IV. The company's performance is higher than the third (III) performance, because the relative cooperation among the customer, manufacture and suppliers relatively very closely. The performance can not be optimal because there is the different perception between customer and supplier. In the research, this happened in centre of leather industry in Manding - Yogyakarta because customers are mostly non-shopping tourist, and the natural disaster / earthquake does not significantly affect to the number of sales.

The mainly obctacle of supplier is in supplying raw materials from suppliers, because colors do not match to the taste of consumers, so production in not in optimum condition. But with more creativity and take more time the manufacture can meet the consumer demand.

Then, the equation is $\mathrm{Y} 4=\mathrm{a}+\mathrm{b} 4 \mathrm{X} 4$

Customer Typology- Facing Arc of Integration (IV).

$\mathrm{V}$. The company's performance is highest of all typologies of cooperation integration is veru closely among customer, manufactor and suppliers. The company's performance will be optimal, because there is no different perception between supplier, manufactor and customer in order to reach the satisfaction of all parties

The equation is $\mathrm{Y} 5=\mathrm{a}+\mathrm{b} 5 \mathrm{X} 5$

X5 = Outward-Facing Arc of Integration (V) Typology.

In functional equation of $\mathrm{Y}=\mathrm{aX}+\mathrm{b}$, where :

$\mathrm{Y}=$ company performance

$\mathrm{X}=$ the length of the process chain

$\mathrm{a}=$ the quality of the process chain relationships / slope

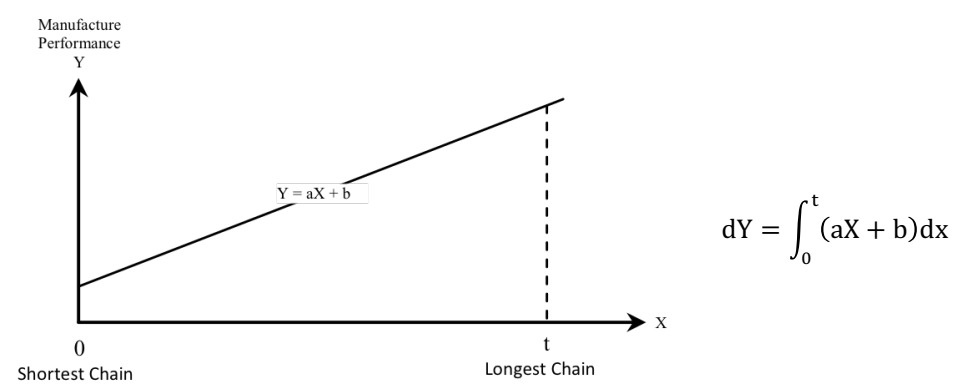

The company's performance is a function of the length of the chain (in the other cases referred to the typology of the supply chain) and the quality of the chain

\section{CONCLUSION}

Based on the description and explanation in previous chapters then, in this study can be summarized as follows:

1. The identification of the typology of SCM integration in leather industrial centers are as follows:

1.1. The typology of small industry is not identified

1.2. Typology of medium indutry is identified as outward facing with the low quality of the relationship. 
1.3. Typology of large industry is identified as outward facing with the qulity of relationship has the higher quality of relationship.

2. There is a difference in the performance of companies that exhibited by companies who practice a different SCM cooperation. The lowest performance shown by the industry that goes on very short chain group (inward facing arc integraty), and the highest performance shown by the industry group that goes a long chain with very high quality relations / strong (facing outward arc integration)

3. Model of cooperation based on the typology of integration in SCM is expressed as a function between the length of the chain of suppliers and the quality of relationships with the company's performance.

4. The research give a strategy that can be used for as a trainning pattern and the development of leather industry by local goverment in Tanggul-angin Sidoarjo or another places with the same leather industri typology in Bojonegoro Regency

\section{References:}

Anderson, M.G ; Katz, P.B. 1998. Strategic sourcing, International Journal of Logistics Management, 9 (1), 1-13.

Andi Ilham S, Bayu A. Sedjarwo, Clara L Benarto, Hoetomo Lembito, Riri Satria, Soerjo Winarto: Produktivitas dan Efisiensi dengan Supply Chain Management. Penerbit PPM. 2006.

Anthony A. Atkinson, Rajiv D Banker, Robert S Kaplan, dan S. Mark Young, Management Accounting, edisi ke dua, New Jersey, Prentice Hall, Inc. 1997. Hal 54.

Carothers, G ; Adams, M. 1991. Competitive Advantage Through Customer Value : The Role of Value-Based Strategies. In: Stahl, MJ, Bounds, GM (Eds), Competing Globally Through Customer Value, Quorum Books, New York, pp. 32-66.

Chopra, Sunil and Peter Meindl 2001. Supply Chain Management, Strategy, Planning and Operation, Prentice Hall, New Jersey.

Cohen, Shoshanan and Roussel, Joseph. 2005. Supply Chain Management, The 5 Disiplines for Top Performance. Mc Graw-Hill. New York.

M. T. Frochlich, R. Westbrook. 2001. Arcs of International Study of Supply Chain Strategies, Journal of Operation Management. Vol, 19.2001.

Gibson, J. L, Ivancevich J. M. dan Donelly Jr J. H. 1987. Organisasi dan Manajemen, Perilaku, Struktur, Proses. Terjemahan Edisi Keempat, Jakarta : Penerbit Erlangga.

Hau L. Lee. The Triple-A Supply Chain. Harvard Business Review. Oktober 2004

Hill, Charles W. L and Jones, Gareth, J. Strategic Management Theory : an Integrated Approach, 4" Edition. Houghton Miffilin Company : NY, 1998.

Hines P; Rich, N; Bicheno, J; Brunt, D. 1998. Value Stream Management. International Journal of Logistics Management 9 (1), 25-42.

Indrajit, Richardus Eko dan Richardus Djokopranoto. 2002. Konsep Supply Chain, Cara Baru Memandang Mata Rantai Penyediaan Barang. PT Gramedia Widiasarana Indonesia, Jakarta.

Kaplan, Robert S, and David P. Norton. The Balanced Scorecard : Translating Strategy Into Action. Massachusetts, Hardvard Business Review. 1996.

Krause, Daniel R, Robert B, Handfield and Thomas V Scannel. 1997. An Empirical Investigation of Supplier Develpoment : Reavtive and Strategic Process. Journal of Operations Management, Vol 17 : 39-58.

Krawjewski, Lee J and Larry P. Ritzman. 2002. Operation Management, Strategy and Analysis, Sixth Edition. Prentice Hall, New Jersey.

Keith Goffin, Fred Lemke, Marek Szwejczewski. An Exploratory Study of “Close” Supplier-Manufacturer Relationship. Journal of Operations Management 24 (2006) 189-209.

Kumar, Nirmalya. 1996. The Power of Trast in Manufactur-Retailer Relationship. Hardvard Business Review (November-Desember) : 92-110

Lee, H. L, Padmanabhan, V. Whang S. 1997. Information Distortion in Supply Chain : The Bullwhip Effect. Management Science 43 (4), 546-558. 
Rupiarsieh., \& Santosa, S. H. (2019). Performance Improvement In Order To Improve Competitiveness Analysis On Supply Chain Management Integration Strategy Leather Industry In Tanggulangin. Advances in Social Sciences Research Journal, 6(2) 1-17.

Leender, M.R ; Blenkhorn, DL. 1988. Reverse Marketing. The Free Press. New York.

Lummus, R.R ; Vokurka, R.J; Alber K. L. 1998. Strategic Supply Chain Planning, Production and Inventory. Management Journal 39 (3) 49-58.

Malhotra, Naresh, K. Marketing Research, An Applied Orentation, Fourth edition. New Jersey : Prentice Hall. 1994.

Martin Christopher. Logistic and Supply Chain Management : Strategics for Reducing Cost and Improving Service. 2nd ed. Britain : Prentice Hall. 1988.

Monezka, R.M; Trent, R.J; Callahan T.J, 1993, Supply base strategies to maximize supplier performance, International of Journal of Physical Distribution \& Logistics Management 23(4), 42-54.

Narasimhan, Ram, Srinivas Talluri and David Mendez (2001), Supplier Evalution and Rationalization via Data Envelopment Analysis : An Empirical Examition. The Journal Of Supply Chain Mnagement 23(4), 42-54.

Narasimhan, R; Jayaram, J, 1998, Causal linkages and supply chain management : an exploratory study of North American manufacturing firms, Decision Sciences 29 (3), 579-605.

Pabundu Tika, 2006, Budaya Organisasi dan Peningkatan Kinerja Perusahaan, PT Bumi Aksara, Jakarta.

Pause, 1999. Pengukuran Efisiensi Data Envelopment Analysis (DEA) Modul Pelatihan, Metodo;ogi Penelitian Empiris Metodologi Penelitian Empiris Metode Kuantitatif Ekonomi dan Bisnis. Pusat Antar Universitas Studi Ekonomi UGM.

Primo, M.A.M.Amundson, S. D. 2002. An Explanatory Study of Supplier Relationships on New Product Development Outcomes. Journal of Operation Management 20 (1). 33-52.

Ragatz, GL; Handfield, RB ; Scannell, TV. 1997. Succes Factor for Integrating Supplier Into New Product Development. Journal of Product Innovation Management. 14, 190-202.

Rampersad Huber K. 2005. Total Performance Scorecard : Konsep Manajemen Baru Mencapai Kinerja dengan Integritas. Penerbit PT Gramedia Pustaka Utama.

Robert S Kaplan dan David P. Norton. The Balanced Scorecard : Translating Strategy Into Action. Massachusetts. Harvard Bussiness School Press. 1996.

Robbins S. P. 1994. Organizations Theory : Structure, Design and Applications (Terjemahan). Jakarta : Penerbit Arcen.

Saunders, M. 1997. Strategic Purchasing and Supply Chain Management. Pitman Publishing. London.

Scannel, Thomas V, Shawnee K. Vickery and Cornelia L Druge (2000). Upstream Supply chain Management and Competitive Performance in the Automotive Industry. Journal of Bussiness Logistics, vol 21, no 1 : 23-48.

Sentono Prawiro, 1999, Manajemen Sumber Daya Manusia Kebijakan Kinerja Karyawan, BPFE, Yogyakarta.

Shapiro, JF ; Shinghal, VM ; Wagner, SN, 1993, Optimizing the value chain, Interfaces 23 (2), 102-117.

Simchi-Levi, David, Philip Kaminsky, Edith Simchi-Levi, “Designing and Managing The Supply Chain : Concepts, Strategies, and Case Studies”, Singapore : Mc Graw-Hill:2000.

Soedijani, Nanik, 2005, Comestic in Indonesia, International Bussiness Strategies,

(Download 18 Mei 2008)

Sony Yuwono, Edy Sukarno, Muhammad Ichsan, Petunjuk Praktis Penyusunan Balanced Scorecard Manuju Organisasi Yang Berfokus Pada Strategi, PT. Gramedia Pustaka Utama, Jakarta, 2002.

Stevens, J, 1989, Integrating the supply chain, International Journal of Physical Distribution and Materials Management 19 (8), 3-8.

Suharyadi dan Purwanto S.K (2004), Statistika Untuk Ekonomi dan Keuangan Modern, Salemba Empat, Jakarta. Suhong Li S; Subba Rao.TS; Ragu-Nathan; Bhanu Ragu-Nathan, Development and Validation of a measurement instrument of studying supply chain management practices, Journal of Operation Management 23 (2005) 618641.

Supriyanto, Agus dan Ida Masruchah (2000), Manajemen Puchasing : Strategi Pengadaan dan Pengelolaan Material Untuk Perusahaan Manufacturing, PT Elex Media Komputindo, Jakarta.

Spina, G, Zotteri, G, 2000, The Implementation process of costumer-supplier partnership : lessons from a clinical perspective, International Journal of Operations and Production Management, 20 (10), 1164-1182. 
Suroso Imam (2007), Pengaruh Orientasi Pasar, Karakteristik Pasar Dan Kreativitas Terhadap Inovasi Dan Kinerja Pemasaran Perusahaan Kosmetik di Provinsi Jawa Timur, Disertasi, Program Pasca Sarjana Universitas Airlangga Surabaya.

Trent, RJ ; Monezka, RM , 1998, Purchasing and suppy maagement : trends and changes throughout the 1990s. International Journal of Purchasing and Materials Management Fall, 2-11.

Venkratraman, N and Ramanujam, V. 1986. Measurement of Business Performance in Strategy Research : A Comparison Approaches. Academy of Management Review. Vol. 11 : pp-801-814.

Waterhouse, Jhon and Svendsen Ann. 1988. Strategic Performance Monitoring and Management: Using Non Financial Measures to Improve Corporate Governance. The Canadian Institute of Chartered Accountant.

Yolanda, M. Siagian. 2005. Aplikasi Supply Chain Management dalam Dunia Bisnis. Penerbit PT Gramedia Widiasarana Indonesia, Jakarta.

Ziropli, F. Caputo, M. 2002. The Nature of Buyer-Supplier Relationships in co-design Activities : The Italian Auto Industry Case. International Journal of Production and Operations Management. 22 